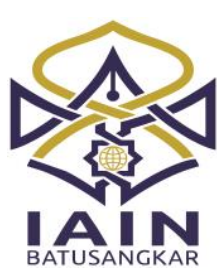

JURNAL TA'DIB, Vol 23 (2), 2020, (Juli-Desember)

ISSN: $1410-8208$ (Print) 2580-2771 (Online)

Tersedia online di http://ecampus.iainbatusangkar.ac.id/ojs/index.php/takdib/index

\title{
Implementasi Program Madrasah Tahfidz Kemenag DIY di Madrasah Aliyah Negeri se-Kota Yogyakarta
}

\section{The Implementation of Madrasa Tahfidz program of Ministry of Religion DIY}

Received: 17-04-2020; Revised: 15-10-2020; Accepted: 09-11-2020 Published: 28-12-2020

\section{Afiq Fikri Almas*) \\ Universitas Islam Negeri Sunan \\ Kalijaga Yogyakarta \\ E-mail: afiqfikri626@gmail.com}

\section{Imam Machali}

Universitas Islam Negeri Sunan Kalijaga Yogyakarta

E-mail:imammachali79@gmail.com

*) Corresponding Author
Abstract: The Implementation of Madrasa Tahfidz program of Ministry of Religion DIY has not been evenly distributed. This was the basis for the researchers to evaluate the program especially in MAN 1 and MAN 2 Yogyakarta. This evaluation research used an objectiveoriented approach to measure the objective level of achievement program and used mixed methods with a concurrent embedded model. The CIPPO (Context, Input, Process, Product, and Outcome) evaluation model was used to analyze the program. The researcher used purposive sampling and snowballing sampling techniques in determining the subjects. The results show that overall the Madrasa Tahfidz program was quite effective because input, process, and outcomes of evaluated CIPPO components were optimally fulfilled. It is produce recommendations for revising the program, because there are still 2 components cannot be assessed as effective and still need continuous improvement. Context has not been effective because student need components are more needed in improving of reading Quran rather than memorizing. The product of program is not yet effective because referring to three measuring instruments that produce an average measurement result at a moderate level with a percentage $(46.6 \%)$, either by sex, origin of madrasa and class of students, and haven't reached a high level.

\begin{abstract}
Abstrak: Implementasi program Madrasah Tahfidz Kementerian Agam: DIY belum merata antara satu madrasah dan lainnya. Hal inilah yan menjadi dasar bagi peneliti untuk mengevaluasi program tersebu terutama di MAN 1 dan MAN 2 Yogyakarta. Penelitian evaluasi in menggunakan pendekatan yang berorientasi pada tujuan untuk menguku: tingkat pencapaian program dan menggunakan metode campuran dengar model concurrent embedded. Model evaluasi CIPPO (Context, Input Process, Product, and Outcome) digunakan untuk menganalisis program Peneliti menggunakan purposive sampling dan teknik snowballin sampling dalam menentukan subjek yang berkualitas. Hasil penelitiar menunjukkan bahwa efektivitas keseluruhan program Madrasah Tahfid: "cukup efektif" karena input, proses, dan outcome dari komponen CIPPC yang dievaluasi terpenuhi secara optimal, dan menghasilkan rekomendas untuk merevisi program, karena masih ada 2 komponen yang tidak dapa dinilai efektif dan masih perlu perbaikan terus menerus. Konteks belun efektif karena komponen kebutuhan siswa lebih dibutuhkan dalan meningkatkan membaca Alquran dari pada menghafal. Produk progran belum efektif karena merujuk pada tiga instrumen pengukuran yan menghasilkan hasil pengukuran rata-rata pada tingkat sedang dengar persentase $(46,6 \%)$, baik berdasarkan jenis kelamin, asal madrasah ataı kelas siswa, dan belum mencapai tingatakan yang tinggi.
\end{abstract}

Keywords: Efectiveness program, CIPPO, Madrasa Tahfidz 
PENDAHULUAN

$\mathrm{K}$ ementerian Agama Daerah Istimewa Yogyakarta memiliki program - madrasah tahfidz yang di-launching dan dideklarasikan pada hari Ahad tanggal 30 Maret 2014 di GOR Amongrogo Yogyakarta. Program ini ditujukan untuk meningkatkan kualitas Madrasah se-provinsi Daerah Istimewa Yogyakarta. Madrasah tahfidz dapat menjadi brand positif mengatasi persaingan madrasah dengan sekolah umum (Andi, 2017).

Madrasah Aliyah dijadikan pioner dalam pelaksanaan program madrasah tahfidz. Siswa-siswi Madrasah Aliyah ditargetkan hanya untuk menghafalkan juz dua saja. Madrasah Aliyah Negeri 1 Yogyakarta merupakan madrasah piloting yang ditunjuk oleh Kemenag DIY dalam penyelenggaraan program tahfidz. MAN 1 Yogyakarta telah rutin menggelar wisuda tahfidz setiap tahunnya. Pelaksanaan wisuda tahfidz pertama dapat meluluskan 68 siswa (29 putra dan 39 putri). Terdapat siswa yang sudah menghafal 2 juz sampai $30 \mathrm{juz}$ (Mt/dzl, 2017). MAN 2 Yogyakarta juga telah menggelar kegiatan wisuda tahfidz pada setiap tahunnya. Sebanyak 95 siswa mengikuti prosesi wisuda tahfidz di tahun 2018 (Len, 2018). Siswasiswa yang diwisuda merupakan siswa yang minimal telah menghafal 1 Juz sampai 15 Juz. (Len, 2018). MAN 2 Yogyakarta juga merupakan madrasah yang telah mengeluarkan regulasi pada tahun pelajaran 2018/2019, untuk memasukkan tahfidz pada program intrakurikuler. Kedua madrasah inilah yang dapat dijadikan percontohan dalam pelaksanaan program tahfidz yang dicetuskan oleh Kemenag DIY.

Pelaksanaan program tahfidz Kemenag DIY yang seharusnya diwajibkan dalam intrakurikuler, belum sepenuhnya diimplementasikan oleh semua madrasah di DIY (Mukotip, 2018). Banyak penelitian yang sudah mengukur keefektivitasan sebuah program tahfidz di lembaga pendidikan, akan tetapi belum ada penelitian yang mengevaluasi tentang program tahfidz Kemenag DIY ini.
Hafalan Alquran dengan menggunakan metode yanbu'a dan metode muroja'ah di SDI Al Azhar, dan metode tilawati, metode isyarat, dan metode muroja'ah yang digunakan di SD Al-Gontory dapat meningkatkan efektivitas hafalan siswa tahun 2017 (Zahro', 2017). Sedangkan Pembelajaran Baca Tahsin Hafalan Alquran (BTHQ) di SDIT Luqman Al-Hakim Yogyakarta tahun 2017 efektif meningkatkan hafalan Alquran peserta didik (Mardhiyah, 2017). Kedua penelitian tersebut mengkaji program internal lembaga pendidikan yang diaplikasikan terhadap program tahfidz dalam satu instansi saja. Berbeda halnya dengan program tahfidz Kemenag DIY yang diaplikasikan terhadap seluruh lembaga pendidikan di bawah naungan Kemenag DIY.

Berdasarkan hal tersebut keterlaksanaan program madrasah tahfidz ini harus didukung dengan adanya evaluasi. Sesuai dengan Undang-Undang No. 20 Tahun 2003 tentang Sistem Pendidikan Nasional dalam BAB XVI bagian kesatu perihal Evaluasi Pasal 57 ayat (2): "Evaluasi dilakukan terhadap peserta didik, lembaga, dan program pendidikan pada jalur formal dan non formal untuk semua jenjang, satuan, dan jenis pendidikan"(Undang-Undang No 20 Tahun 2003 Tentang Sistem Pendidikan Nasional, 2003). Penelitian ini bertujuan untuk mengevaluasi efektivitas keseluruhan dari program madrasah tahfidz Kemenag DIY di MAN se-Kota Yogyakarta dengan mengidentifikasi efektivitas kontek, input, proses, produk dan outcome program madrasah tahfidz. Dengan demikian, maka akan dapat dilakukan penyempurnaan program apabila masih terdapat kekurangan.

\section{METODE PENELITIAN}

Penelitian ini menggunakan pendekatan evaluasi (evaluation research) (Asrori, 2014; Sukmadinata, 2012) yang berorientasi pada tujuan program. Penelitian ini menggunakan metode kombinasi kualitatif dan kuantitatif (mixed methods) dengan model/strategi concurrent embedded (Sugiyono, 2015). Metode kualitatif sebagai metode primer untuk mengevaluasi kontek, input, proses dan 
outcome (CIPO) program madrasah tahfidz. Sedangkan metode kuantitatif sebagai metode sekunder untuk mengevaluasi produk (P) program madrasah tahfidz. Peneliti menggunakan teknik purposive sampling dalam menentukan subyek kualitatif, sedangkan subjek kuantitatif menggunakan simple random sampling (Sugiyono, 2013). Teknik pengambilan sampel untuk kuantitatif menggunakan rumus Taro Yamane atau Slovin (Sugiyono, 2013) dengan tingkat penyimpangan $8 \%$ menghasilkan 116 sampel siswa dari 454 siswa kelas XI MAN 1 dan MAN 2 Yogyakarta. Teknik pengumpulan data yang digunakan dalam penelitian ini adalah wawancara, observasi, dokumentasi dan angket. Teknik analisis data dengan cara mereduksi data, menyajikan data, dan menarik kesimpulan.

\section{HASIL DAN PEMBAHASAN}

Program tahfidz MAN 1 Yogyakarta dan MAN 2 Yogyakarta berdasarkan kebijakan dari Kementerian Agama Daerah Istimewa Yogyakarta dievaluasi dan diukur keefektivitasannya melalui paradigma context, input, process, product dan outcomes-nya (CIPPO).

Model evaluasi CIPP Stufflebeam (Arifin, 2009; Asrori, 2014; Safruddin, 2014) yang disempurnakan oleh Gilbert Sax menjadi model evaluasi CIPPO (Widoyoko, 2014) digunakan untuk menganalisis program madrasah tahfidz berdasarkan komponenkomponennya. Menurut Stufflebeam lingkup evaluasi program meliputi empat tingkatan yaitu evaluasi konteks, evaluasi input, evaluasi proses, dan evaluasi produk. Model CIPP Stufflebeam ini disempurnakan oleh Gilbert Sax dengan menambahkan satu komponen O yaitu outcome menjadi CIPPO. Outcome adalah implementasi dari produk (Safruddin, 2014), keefektivitasan dari keseluruhan program Madrasah Tahfidz sebagaimana berikut:

\section{Evaluasi Context}

Evaluasi konteks berupaya untuk menggambarkan dan merinci lingkungan, kebutuhan yang tidak terpenuhi dan tujuan proyek (Suryono, 2015). Kebutuhan- kebutuhan peserta didik yang berhubungan dengan Alquran atau tahfidz dijabarkan dalam peningkatan potensi hafalan dan kekurangan serta keluhan program.

Masing-masing madrasah memiliki karakter, target, program, dan metode yang berbeda-beda dalam pembelajaran tahfidz Alquran (Uswatun, 2019). Berdasarkan inilah maka madrasah masih banyak memiliki kebutuhan dalam pembelajaran tahfidz. Kriteria peserta didik yang sudah dapat menghafal dengan baik dan benar itu hanya sedikit. Masih banyak juga peserta didik MAN 1 Yogyakarta yang membutuhkan pembenaran dalam tajwid (Luthfiana, 2019). Kebutuhan kedua madrasah tersebut sudah dapat dibaca oleh ibu Dra. Uswatun Hasanah sebagai kepala seksi pendidikan madrasah Kemenag Kota Yogyakarta.

Lain halnya dengan beberapa pendapat di atas, kepala seksi sarana dan prasarana bidang pendidikan madrasah Kemenag DIY tahun 2015 yang pertama kali merumuskan gerakan tahfidz menyampaikan kebutuhan madrasah bahwa lulusan madrasah hampir sebagian besar tidak tercapai kompetensi BTQ-nya. Sedangkan sebagian kompetensi BTQ yang tercapai bukan merupakan peran dari madrasah. Siswa dapat membaca dan menulis Alquran bukan merupakan peran penuh madrasah, akan tetapi dikarenakan hasil pembelajaran Alquran di luar madrasah. (Fauzi, 2019)."

Secara garis besar memang kebutuhan dari peserta didik baik di MAN 1 Yogyakarta maupun MAN 2 Yogyakarta adalah perbaikan bacaan Alquran atau tahsin Alquran. Kedua madrasah pun sudah memfasilitasi dalam pemenuhan kebutuhan tersebut dengan diadakannya matrikulasi atau pembenaran dan pengayaan bacaan Alquran. Matrikulasi ini dilakukan selama beberapa bulan saja dan belum dipandang cukup untuk memenuhi dan memperbaiki bacaan peserta didik dengan baik dikarenakan waktunya yang singkat. Kebutuhnan dari kedua madrasah tersebut sudah diusahakan oleh masing-masing madrasah untuk dapat terpenuhi walaupun belum dapat memberikan 
dampak yang besar terhadap peningkatan kompetensi Alquran peserta didik.

Terdapat beberapa keluhan yang muncul dari adanya program tahfidz ini. Kekurangan dari pihak pemangku kebijakan untuk tahun 2018 tergambarkan dengan belum adanya anggaran khusus untuk program tahfidz (Uswatun, 2019). Selama ini program tahfidz yang diselenggarakan pada masing-masing madrasah belum sama, terdapat sebagian madrasah yang sudah memasukan program tahfidz dalam intrakurikuler, sebagian lainnya masih ditempatkan pada program ekstrakurikuler. Hal ini terjadi walaupun sudah ada himbauan untuk melaksanakan program tahfidz pada kegiatan intra (Imanah, 2018).

Penulis mengkategorikan keluhan ini menjadi dua macam, dari segi pengelolaan dan materi. Kendala yang dihadapi oleh MAN 1 Yogyakarta terletak ketika jam inovasi Alquran yang mendatangkan guru tahfidz dari luar madrasah. Karena kesibukan guru tahfidz yang notabene adalah guru yang didatangkan dari luar madrasah, banyak yang meminta izin mengajar dikarenakan kesibukan di luar madrasah. Hal ini membuat pengelola harus cepat memberikan tugas pengganti ataupun mencarikan guru pengganti (Suyanto, 2019). Kendala pengelolaan juga didapati MAN 2 Yogyakarta. Program matrikulasi yang dilaksanakan belum banyak memberikan dampak peningkatan pada peserta didik (Mahardika, 2019).

Materi ajar yang masih kurang tepat sasaran banyak dirasakan pada program tahfidz dari kedua madrasah. Juz 2 yang disyaratkan oleh Kemenag DIY masih dirasa berat apabila digeneralkan untuk seluruh peserta didik. Nurul Alfi Laili, S.Psi guru tahfidz MAN 1 Yogyakarta menyampaikan bahwa program hafalan juz 30 pada tahun 2017 sudah dianggap tepat untuk peserta didik. Target ini sebenarnya masih perlu banyak peningkatan, karena masih banyak anak yang belum mencapai standar. Hal ini dikarenakan peserta didik memiliki latar belakang yang berbeda. Sehingga akan lebih banyak kesulitan apabila peserta didik harus mencapai target hafalan juz 2 .
Fajar Basuki Rahmat, S.Ag. menganjurkan agar target hafalan tidak harus menyelesaikan juz 2. Hal ini dikarenakan masing-masing peserta didik madrasah memiliki karakter yang berbeda-beda dalam menghafalkan Alquran. Terdapat peserta didik yang sudah mempunyai hafalan juz 30 atau bahkan juz 29. Di sisi lain masih terdapat juga peserta didik yang belum mampu membaca Alquran. Kebutuhan umum yang paling penting bagi peserta didik di madrasah adalah dapat membaca Alquran dengan baik dan benar. Bukan menghafalkan Alquran secara langsung. Hal itu sudah dianggap tepat untuk peserta didik aliyah di MAN 2 Yogyakarta.

Munculnya kebijakan program tahfidz Kemenag DIY pada madrasah di kota Yogyakarta khususnya dan umumnya madrasah di seluruh provinsi DIY adalah dalam rangka menyiapkan kader peserta didik madrasah yang hafal Alquran.

Target linier yang sudah ditetapkan apabila diikuti peserta didik mulai dari Raudhotul Athfal (RA)/taman kanak-kanak hingga Madrasah Aliyah adalah dapat menyelesaikan 4 juz. Tingkat RA diharapkan dapat menyelesaikan juz 30, Madrasah Ibtidaiyah dapat menyelesaikan juz 29, dan Madrasah Tsanawiyah untuk menyelesaikan juz 1, sedangkan Madrasah Aliyah diharapkan dapat menyelesaikan juz 2 (Imanah, 2018). Secara komprehensif tujuan program tahfidz ini adalah untuk meningkatkan hafalan peserta didik madrasah dengan menghantarkan mereka untuk tuntas menyelesaikan 4 juz setelah selesai pendidikan di Madrasah Aliyah dengan syarat mengikuti jenjang lembaga pendidikan di bawah Kementerian Agama.

Penggagas gerakan tahfidz memberikan pengertian bahwa sebenarnya sasaran utama dari program ini adalah tuntas baca tulis Alquran yang dikemas dalam kegiatan tahfidz Alquran. Sehingga sedikit terjadi disorientasi antara tujuan awal dicanangkannya program tahfidz dengan tujuan yang dilaksanakan sekarang (Fauzi, 2019).

Mewujudkan siswa-siswi madrasah yang religius, berakhlakul karimah, cerdas, 
mandiri, dan berintegritas juga merupakan tujuan dicanangkannya program tahfidz ini. Hal ini untuk menyiapkan peserta didik madrasah yang punya sifat religiusitas tinggi. Di samping untuk mewujudkan tujuan pendidikan, program ini berfungsi untuk membentuk peserta didik yang mandiri, cerdas, dan berintegritas (Imanah, 2018).

H. Nadhif, S.Ag., M.S.I. memaparkan dalam pengantar Kepala Bidang Dikmad Kanwil Kemenag DIY pada modul pembelajaran tahfizh bahwa program ini untuk meningkatkan religiusitas madrasah melalui hafalan Alquran dan membumikan nilai-nilai Alquran agar menjadi karakter dan budaya siswa madrasah (Nurhadi, 2018).

\section{Efektivitas Input}

Evaluasi Input atau evaluasi masukan menurut Stufflebeam berkenaan dengan kondisi awal dan sub komponen masukan yang mendorong diselenggarakannya program yang bersangkutan. Evaluasi masukan membantu mengatur keputusan, menentukan sumber-sumber yang ada, alternatif apa yang diambil, apa rencana dan strategi untuk mencapai tujuan, dan bagaimana prosedur kerja untuk mencapai tujuan dari program madrasah tahfidz (Widoyoko, 2014).

Orientasi utama evaluasi input adalah menentukan cara bagaimana tujuan program dicapai. Evaluasi masukan dapat membantu mengatur keputusan dan menentukan bagaimana prosedur kerja untuk mencapainya (Wahyudhiana, 2015). Masukan program madrasah tahfidz dievaluasi melalui empat komponen, yang terdiri dari kesesuaian kurikulum dengan kebutuhan peserta didik, pengajar/guru tahfidz yang memenuhi kualifikasi, sarana prasarana yang mendukung pelaksanaan program, dan penanggung jawab kebijakan keterlaksanaan program.

Pertama, pelaksanaan program tahfidz dimasukan pada kurikulum dan muatan lokal (mulok). Program tahfidz untuk tingkatan RA, MI, dan MTs dimasukan pada mulok, sedangkan untuk tingkatan MA dapat dimasukan pada mulok ataupun pada program lintas minat. MAN 1 Yogyakarta sendiri sudah melaksanakan program tahfidz di dalam intrakurikuler sejak tahun 2016 dan digunakan sebagai syarat kenaikan kelas $\mathrm{X}$ dengan minimal hafalan 30 surat pilihan (Laili, 2019).

Tahfidz intrakurikuler yang dilaksanakan oleh MAN 1 Yogyakarta didukung dengan kegiatan tahfidz ekstrakurikuler. Walaupun begitu, setiap guru dan pengajar dari masingmasing program baik intra maupun ekstra sama-sama saling berkoordinasi untuk mengetahui batas bacaan dari peserta didik yang diampu. Program intra memiliki 2 guru tahfidz, sedangkan 16 guru mengajar pada program ekstra. Kegiatan tahfidz ekstra dilaksanakan setelah dhuhur dari 12.30 WIB sampai jam 14.15 WIB melalui kegiatan belajar mengajar (KBM) khusus. Jam kegiatan khusus ini dinamakan dengan jam inovasi.

Satu visi dengan MAN 1 Yogyakarta dalam perihal program tahfidz, MAN 2 Yogyakarta sudah melaksanakan program sejak tahun 2016 dengan waktu pembelajaran tersendiri di luar jam pembelajaran atau setelah jam pembelajaran. Tahun 2017 MAN 2 Yogyakarta menerapkan program dengan dua model. Pertama dilaksanakan dalam ekstra tahfidz dengan jadwal pertemuan satu minggu sekali dan dengan ektra tahfidz. melalui dua kali pertemuan dalam seminggu pada hari senin dan selasa. Pada tahun pelajaran 2018-2019 atas mandatori dari kanwil Kemenag DIY, maka program tahfidz di MAN 2 Yogyakarta dimasukan dalam kurikulum intra untuk kelas $\mathrm{X}$ dan XI, sedangkan untuk kelas XII dilaksanakan tahfidz sebelum pembelajaran di jam pagi.

Pemenuhan kebutuhan peserta didik tentang kompetensi membaca dan menghafal Alquran sebenarnya belum terlalu maksimal dapat diupayakan oleh kedua madrasah. MAN 1 Yogyakarta belum dapat sepenuhnya meng-cover kebutuhan Alquran peserta didik dikarenakan madrasah memiliki banyak program yang juga harus diselesaikan (Suyanto, 2019). Hal ini juga terjadi di MAN 2 Yogyakarta, program ini dirasa kurang tepat sasaran. Bahkan salah satu guru di MAN 2 Yogyakarta sempat mengusulkan kepada 
Bidang Pendidikan Madrasah Kemenag DIY untuk tidak menerapkan program ini kepada seluruh jurusan yang ada di madrasah. Program tahfidz yang sudah memiliki modul ini, seharusnya bisa diaplikasikan khusus di kelas agama. Madrasah yang memiliki kelas program agama dapat meng-explore kebutuhan dan pelaksanaan program khusus tahfidz (Mahardika, 2019)."

Kedua, sumber daya manusia yang dimanfaatkan untuk mengajar program tahfidz memberdayakan guru-guru yang sudah dapat membaca dan menulis Alquran dengan baik dan benar. Hal ini merupakan standar minimal dari guru tahfidz. Atau lebih dari itu, guru harus sudah mempunyai hafalan Alquran baik penuh ataupun tidak. Selain itu juga dapat mendatangkan atau mengundang guru tahfidz khusus dari pihak luar madrasah.

MAN 1 Yogyakarta memberdayakan guru agama dalam melaksanakan program tahfidz. Akan tetapi kebijakan ini kemudian diperbarui dengan mengangkat guru tetap dua orang untuk mengajar tahfidz dalam kelas intra. Kemudian MAN 1 Yogyakarta mengundang guru-guru tahfidz dari luar untuk mengajar tahfidz pada jam inovasi. (Suyanto, 2019).”

Hal yang hampir sama juga didapatkan di MAN 2 Yogyakarta, bahwa tahfidz diampu oleh guru-guru mata pelajaran Pendidikan Agama Islam dan Bahasa Arab. Pengajar Pendidikan Agama Islam dan Bahasa Arab di MAN 2 Yogyakarta semuanya dengan jumlah 12 guru ikut andil dalam pengajaran tahfidz tanpa mengundang atau menggunakan guru tahfidz dari luar madrasah (Rahmat, 2019).

Pengajar tahfidz dari kedua madrasah rata-rata sudah memenuhi kualifikasi sebagai pengajar tahfidz. Pengajar tahfidz ektra MAN 1 Yogyakarta yang didatangkan dari luar ratarata sudah hafidz (memiliki hafalan Alquran) atau sudah menyelesaikan hafalan 30 juz. Sedangkan pengajar tahfidz yang notabene guru MAN 1 Yogyakarta dipilih dengan ketentuan guru yang sudah baik tahsin, tajwid, dan pemahaman Alqurannya. Karena memang tidak ada kewajiban bahwa pengajar tahfidz harus sudah hafal Alquran 30 juz. Sedangkan MAN 2 Yogyakarta memiliki 2 guru yang sudah hafidz. Selain itu yang diamanahi untuk menjadi guru-guru tahfidz di MAN 2 Yogyakarta sudah dirasa cukup dan mampu membimbing tahfidz peserta didik meskipun diantara mereka terdapat guru yang belum hafal juz amma. Hal tersebut tidak menjadi masalah karena pengajar tahfidz. sejatinya menjadi pendamping hafalan.

Ketiga, sarana dan prasarana pembelajaran tahfidz secara menyeluruh sudah memenuhi dan mendukung pelaksanaan program. Sarana dan prasarana di MAN 1 Yogyakarta juga sudah memenuhi standar mengajar tahfidz (Laili, 2019). Sarana prasarana yang paling dibutuhkan dalam pengajaran tahfidz adalah modul, Alquran, dan tempat untuk hafalan. Tidak diperlukan sarana yang ribet dan bisa belajar dimana saja asalkan tempat tersebut tempat yang baik, seperti di dalam kelas ataupun di luar kelas.

Sarana prasarana yang terdapat di MAN 2 Yogyakarta selain modul wajib dari Kemenag DIY juga menyediakan buku saku untuk pegangan peserta didik sebagai batas hafalan dan lembar pemantauan hafalan siswa. Selain itu, madrasah juga menyediakan juknis pembelajaran tahfidz dan teknik belajar mengajar tahfidz.

Keempat, pengontrolan dan pengawasan program tahfidz melalui pengawasan dari pengawas madrasah. Sedangkan penanggung jawab pengelolaan dan keterlaksanaan program dimandatkan sepenuhnya kepada madrasah masing-masing (Imanah, 2018). Masing-masing madrasah dianjurkan membuat tim khusus yang terdiri dari guruguru agama dalam pengelolaan program, atau dikelola sepenuhnya oleh wakil kepala madrasah bidang keagamaan. Waka Keagamaan MAN 1 Yogyakarta mengajak beberapa guru agama dan guru tahfidz untuk menjadi tim pengelolaan program tahfidz. Sedangkan pengelolaan program tahfidz di MAN 2 Yogyakarta sepenuhnya dikelola oleh Waka Keagamaan yang bekerja sama dan berkoordinasi dengan Waka Kurikulum dalam pemantauan dan pelaporannya. Hal ini dikarenakan program tahfidz yang sudah masuk sebagai mata pelajaran intrakurikuler. 


\section{Efektivitas Process}

Evaluasi Process diarahkan pada seberapa jauh kegiatan yang dilaksanakan di dalam program sudah terlaksana sesuai dengan rencana. Evaluasi proses untuk mengetahui sampai sejauh mana rencana yang telah diterapkan dan komponen apa yang perlu diperbaiki dalam program madrasah tahfidz.

Evaluasi proses digunakan untuk mendeteksi atau memprediksi rancangan prosedur atau rancangan implementasi selama tahap implementasi, menyediakan informasi untuk keputusan program dan sebagai rekaman atau arsip prosedur yang telah terjadi (Jaeun, 2014). Proses program madrasah tahfidz dievaluasi melalui enam komponen, yang terdiri dari; pendekatan pengajar tahfidz, interaksi dua arah antara pengajar tahfidz dengan peserta didik, peserta didik dapat meningkatkan hafalan Alquran, program tahfidz dilaksanakan sesuai jadwal, lingkungan mendukung pelaksanaan program tahfidz, dan sarana prasarana dimanfaatkan secara optimal.

Pertama, pihak madrasah membebaskan metode dan pendekatan pengajaran tahfidz kepada masing-masing guru, baik di MAN 1 Yogyakarta ataupun MAN 2 Yogyakarta. Metode yang digunakan rata-rata adalah metode masal dan klasikal, dengan pertamatama memberikan motivasi diawal dan membimbing peserta didik untuk hafalan secara masal, kemudian dilanjutkan hafalan secara individual. Setelah kegiatan hafalan individual selesai, masing-masing dari peserta didik menyetorkan hafalan kepada pembimbing/pengajar tahfidz.

Model pembelajaran tahfidz MAN 2 Yogyakarta melalui muraja'ah setoran yang berdasarkan buku pedoman, kemudian disetorkan kepada pembimbing/pengajar tahfidz (Rahmat, 2019). Selain metode muraja'ah dan klasikal, guru secara khusus meminta kepada peserta didik untuk mengulang-ulang beberapa kali hafalannya. Siswa juga diminta untuk memahami makna ayat yang dihafalkan supaya mempermudah hafalannya.

Tidak hanya melalui pengajaran satu arah saja, metode tahfidz yang digunakan juga memberdayakan teman sebangku atau teman sekelas. Guru memberdayakan dan memanfaatkan peserta didik yang sudah memiliki hafalan lebih untuk menjadi tutor teman sebaya dengan teknik yang bermacammacam. Di antara mereka pun bisa saling menyimak satu sama lain.

Masing-masing guru tahfidz baik dari MAN 1 Yogyakarta maupun MAN 2 Yogyakarta sama-sama telah menerapkan pendidikan dan penanaman karakter dalam pengajaran tahfidz. Hal ini terlihat ketika guru tahfidz memulai pengajaran dengan selalu mengingatkan untuk bersikap sopan ketika menghadap dan menghafalkan Alquran. Tidak hanya itu, guru tahfidz juga selalu mengingatkan ketika di akhir pembelajaran untuk berbakti kepada orang tua dan meniatkan hafalan sebagai sodaqah jariyah kepada orang tua.

Kedua, mulai dari awal pembelajaran hingga pembelajaran ditutup selalu ada interaksi dua arah baik dari pengajar tahfidz kepada peserta didik maupun sebaliknya dari peserta didik yang bertanya kepada pengajar tahfidz. Interaksi ini banyak dilakukan karena belajar Alquran tidak dapat dilakukan secara otodidak, tapi justru harus berinteraksi dengan guru. Ketika peserta didik mendapati kesulitan dapat bertanya kepada guru secara langsung dan sebaliknya, ketika guru mendapatkan kesalahan dalam bacaan ataupun hafalan peserta didik guru dapat langsung membenarkannya.

Ketiga, guru tahfidz MAN 2 Yogyakarta selalu menyarankan peserta didiknya untuk me-muraja'ah hafalannya di rumah masingmasing. Muraja'ah hafalan juga dilakukan dengan ustadz-ustadzah-nya masing-masing bagi peserta didik yang bermukim di pondok pesantren. Sedangkan bagi peserta didik yang bermukim di boarding secara otomatis sudah mendapatkan jam khusus muraja'ah hafalan secara berjamaah (Mahardika, 2019).

Salah satu motivasi pendorong peserta didik mau untuk menghafal Alquran sesuai target adalah dikarenakan mereka termotivasi untuk menyelesaikan hafalan agar dapat naik kelas. Selain itu, terdapat juga beberapa peserta didik yang sudah memahami akan 
manfaat menghafal Alquran sehingga mereka benar-benar serius dalam menyelesaikan hafalan.

Pernyataan ini membuktikan bahwa sudah terdapat peningkatan hafalan peserta didik walaupun masih sedikit. Seperti halnya peserta didik yang belum lancar menghafalkan Alquran mendapatkan dorongan dan pembiasaan untuk menghafalkan Alquran, akhirnya dapat lancar dalam membaca Alquran.

Keempat, program Tahfidz dikendalikan dengan beberapa macam pengelolaan baik di MAN 1 Yogyakarta ataupun MAN 2 Yogyakarta. Terdapat intra dan ekstra program tahfidz dengan pembimbing tahfidz yang masuk kelas sesuai apa yang sudah dijadwalkan. Guru tahfidz sama-sama mengajar dengan durasi waktu satu minggu satu pertemuan dan hanya 1 jam pelajaran, yang sudah sesuai dengan jadwal mengajar (Laili, 2019; Luthfiana, 2019). Pelaksanaan program tahfidz yang sudah sesuai jadwal juga dilakukan di MAN 2 Yogyakarta.

Kelima, tidak hanya dari pihak pemangku kebijakan yang notabene Kementerian Agama baik di provinsi atau kabupaten/kota saja yang mendukung program tahfidz ini. Program ini juga sepenuhnya didukung oleh seluruh keluarga besar madrasah di masingmasing madrasah. Semua warga madrasah sudah mendukung program tahfidz. Hal ini tergambarkan dengan diadakanya jam inovasi di MAN 1 Yogyakarta. Dukungan terhadap program tahfidz juga didapatkan di MAN 2 Yogyakarta. MAN 2 Yogyakarta mendukung program tahfidz dengan mengadakan PETUAH (Pesantren Sabtu Ahad). Program ini akan membimbing peserta didik dalam meningkatan kompetensi keagamaan, seperti halnya bagaimana peserta didik dapat menghafalkan Alquran dan doa-doa keseharian. Program dilaksanakan secara bergantian tiap kelas pada setiap minggunya.

Keenam, proses pembelajaran tahfidz memanfaatkan sarana dan prasarana di kelas selayaknya pembelajaran materi pelajaran lainnya. Madrasah tetap menggunakan kelas sebagai tempat utama pembelajaran dan spidol, papan tulis, serta penghapus sebagai sarana pembelajarannya. Sarana berupa modul yang diproduksi oleh Kemenag dan tim penyusunnya sudah di-launching dari Kanwil Kemenag DIY dan digunakan di madrasah seluruh provinsi DIY baik negeri maupun swasta. (Suyanto, 2019). Modul ini disusun oleh beberapa perwakilan dari madrasah-madrasah se-DIY.

Fakta dilapangan menemukan bahwa modul yang disusun oleh Kemenag DIY belum sepenuhnya dapat diaplikasikan di MAN 2 Yogyakarta. Hal ini dikarenakan karakter kompetensi Alquran peserta didik masih beraneka ragam dan masih banyak peserta didik yang menghafalkan juz 30 . Walaupun begitu tetap ada peserta didik yang hafalannya melebihi 5 juz. Modul tahfidz apabila diaplikasikan ke seluruh peserta didik madrasah nyaris mustahil dapat diaplikasikan sepenuhnya. Hanya 50\% saja yang dapat mengaplikasikannya. Akan tetapi pihak Dikmad Kemenag DIY bersama tim penyusun berharap sambil diaplikasikan modul yang sudah ada akan dibuat materi yang lebih pas lagi untuk diaplikasikan (Mahardika, 2019).

\section{Efektivitas Product}

Evaluasi Product diarahkan pada hal-hal yang menunjukkan perubahan yang terjadi pada masukan mentah (dalam program madrasah tahfidz yang menjadi masukan mentah adalah siswa yang menjadi peserta program ini). Evaluasi produk merupakan penilaian yang dilakukan untuk mengukur keberhasilan dalam pencapaian tujuan yang telah ditetapkan.

Penelitian ini dalam mengukur keefektivitasan produk menggunakan satu variabel independen saja. Variable ini diukur seberapa besar efektivitasnya. Karakteristik populasi akan dijelaskan dalam bentuk tabel frekuensi dan persentase.

Komposisi sampel produk kebijakan madrasah tahfidz Kemenag DIY dikelompokkan menjadi tiga; komposisi sampel berdasarkan jenis kelamin, komposisi sampel berdasarkan sekolah, dan komposisi sampel berdasarkan kelas. Komposisi sampel berdasarkan jenis kelamin digambarkan sebagaimana berikut: 
Tabel 1. Komposisi Sampel Berdasarkan Jenis Kelamin

\begin{tabular}{|l|l|l|l|}
\hline \multicolumn{2}{|c|}{} & Frequency & Percent \\
\hline \multirow{3}{*}{ Valid } & Laki-laki & 49 & 42,2 \\
\cline { 2 - 4 } & Perempuan & 67 & 57,8 \\
\cline { 2 - 4 } & Total & 116 & 100,0 \\
\hline
\end{tabular}

Berdasarkan tabel 1. dapat diketahui dari 116 peserta didik, peserta didik berjenis kelamin laki-laki sebanyak 49 orang $(42,2 \%)$ dan peserta didik berjenis kelamin perempuan sebanyak 67 orang $(57,8 \%)$. Sedangkan komposisi sampel berdasarkan sekolah digambarkan sebagaimana berikut:

Tabel 2. Komposisi Sampel Berdasarkan Madrasah

\begin{tabular}{|l|l|l|l|}
\hline \multicolumn{2}{|c|}{} & Frequency & Percent \\
\hline \multirow{3}{*}{ Valid } & MAN 1 & 58 & 50,0 \\
\cline { 2 - 4 } & MAN 2 & 58 & 50,0 \\
\cline { 2 - 4 } & Total & 116 & 100,0 \\
\hline
\end{tabular}

Berdasarkan tabel 2. dapat diketahui sejumlah 116 peserta didik terdiri dari 58 orang $(50 \%)$ berasal dari MAN 1 Yogyakarta dan 58 lainnya $(50 \%)$ berasal dari MAN 2 Yogyakarta. Komposisi sampel berdasarkan kelas digambarkan sebagaimana berikut:

Tabel 3. Komposisi Sampel Berdasarkan Kelas

\begin{tabular}{|l|l|l|l|}
\hline \multicolumn{2}{|c|}{} & Frequency & Percent \\
\hline \multirow{4}{*}{ Valid } & IPA & 53 & 45,7 \\
\cline { 2 - 4 } & IPS & 39 & 33,6 \\
\cline { 2 - 4 } & IBB & 10 & 8,6 \\
\cline { 2 - 4 } & IIK & 14 & 12,1 \\
\cline { 2 - 4 } & Total & 116 & 100,0 \\
\hline
\end{tabular}

Berdasarkan tabel 3. dapat diketahui dari 116 peserta didik terdiri dari 53 orang $(45,7 \%)$ berada di kelas IPA, 39 orang $(33,6 \%)$ berada di kelas IPS, 10 orang $(8,6 \%)$ berada di kelas IBB, dan 14 orang $(12,1 \%)$ berada di kelas IIK.

Distribusi frekuensi data produk kebijakan madrasah tahfidz Kemenag DIY disajikan dalam distribusi tingkat hafalan dan didukung dengan distribusi silang yang dikelompoknya menjadi tiga; jenis kelamin dengan tingkat hafalan, madrasah dengan tingkat hafalan, dan kelas dengan tingkat hafalan. Distribusi frekuensi tingkat hafalan digambarkan sebagaimana berikut:

Tabel 4. Distribusi Frekuensi Tingkat Hafalan

\begin{tabular}{|l|l|l|l|}
\hline \multicolumn{2}{|c|}{} & Frequency & Percent \\
\hline \multirow{4}{*}{ Valid } & Rendah & 30 & 25,9 \\
\cline { 2 - 4 } & Sedang & 54 & 46,6 \\
\cline { 2 - 4 } & Tinggi & 32 & 27,6 \\
\cline { 2 - 4 } & Total & 116 & 100,0 \\
\hline
\end{tabular}

Berdasarkan tabel 4. dapat diketahui bahwa dari 116 responden mayoritas berada pada tingkat hafalan sedang yaitu sebanyak 54 orang $(46,6 \%)$. Selanjutnya sebanyak 32 orang $(27,6 \%)$ berada pada tingkat hafalan tinggi. Sisanya sebanyak 30 orang $(25,9 \%)$ memiliki hafalan pada tingkat rendah. Tabel silang antara jenis kelamin dengan tingkat hafalan digambarkan sebagaimana berikut:

Tabel 5. Silang antara Jenis Kelamin dengan Tingkat Hafalan

\begin{tabular}{|c|c|c|c|c|}
\hline Jenis & \multicolumn{3}{|c|}{ Total } \\
\cline { 2 - 4 } Kelamin & Rendah & Sedang & Tinggi & \\
\hline Laki-laki & 13 & 25 & 11 & 49 \\
& $11,2 \%$ & $21,6 \%$ & $9,5 \%$ & $42,2 \%$ \\
\hline Perempuan & 17 & 29 & 21 & 67 \\
& $14,7 \%$ & $25,0 \%$ & $18,1 \%$ & $57,8 \%$ \\
\hline Total & 30 & 54 & 32 & 116 \\
& $25,9 \%$ & $46,6 \%$ & $27,6 \%$ & $100 \%$ \\
\hline
\end{tabular}

Berdasarkan tabel 5. dapat diketahui dari 116 responden terdiri dari 49 orang $(42,2 \%)$ berjenis kelamin laki-laki dan 67 orang $(57,8 \%)$ berjenis kelamin perempuan. Dari 49 orang laki-laki, mayoritas sebanyak 25 orang $(21,6 \%)$ memiliki hafalan pada tingkat sedang, 13 orang $(11,2 \%)$ berada pada tingkat rendah, dan 11 sisanya $(9,5 \%)$ memiliki hafalan pada tingkat tinggi. Selanjutnya dari 67 perempuan, mayoritas memiliki hafalan pada tingkat sedang sebanyak 29 orang (25\%), 21 orang $(18,1 \%)$ berada pada tingkat hafalan tinggi, dan sisanya sebanyak 17 orang $(14,7 \%)$ berada pada tingkat hafalan rendah. Tabel silang antara madrasah dengan tingkat hafalan digambarkan sebagaimana berikut:

Tabel 6. Silang antara Madrasah dengan Tingkat Hafalan

\begin{tabular}{|c|c|c|c|c|}
\hline \multirow{2}{*}{ Madrasah } & \multicolumn{3}{|c|}{ Tingkat Hafalan } & \multirow{2}{*}{$\begin{array}{c}\text { Total } \\
\text { Sedang }\end{array}$} \\
\hline & Rendah & Sedang & Rendah & \\
\hline \multirow{2}{*}{ MAN 1} & 11 & 35 & 12 & 58 \\
\hline & $9,5 \%$ & $30,2 \%$ & $10,3 \%$ & $50,0 \%$ \\
\hline MAN 2 & $\begin{array}{c}19 \\
0\end{array}$ & $\begin{array}{c}19 \\
0\end{array}$ & 20 & 58 \\
\hline \multirow{2}{*}{ Total } & 30 & 54 & 32 & 116 \\
\hline & $25,9 \%$ & $46,6 \%$ & $27,6 \%$ & $100 \%$ \\
\hline
\end{tabular}

Berdasarkan tabel 6. dapat diketahui dari 116 responden terdiri dari 58 peserta didik $(50,0 \%)$ berasal dari MAN 1 Yogyakarta dan 58 peserta didik $(50,0 \%)$ berasal dari MAN 2 Yogyakarta. Dari 58 peserta didik yang berasal dari MAN 1 Yogyakarta, mayoritas sebanyak 35 peserta didik $(30,2 \%)$ memiliki hafalan pada tingkat sedang, 12 peserta didik $(10,3 \%)$ berada pada tingkat tinggi, dan 11 sisanya $(9,5 \%)$ memiliki hafalan pada tingkat 
rendah. Selanjutnya dari 58 peserta didik yang berasal dari MAN 2 Yogyakarta, mayoritas memiliki hafalan pada tingkat tinggi sebanyak 20 peserta didik $(17,2 \%)$ dan masing-masing 19 peserta didik $(16,4 \%)$ berada pada tingkat hafalan sedang dan rendah.

Tabel silang antara kelas dengan tingkat hafalan digambarkan sebagaimana berikut:

Tabel 7. Silang antara Kelas dengan Tingkat Hafalan

\begin{tabular}{|c|c|c|c|c|}
\hline \multirow{2}{*}{ Kelas } & \multicolumn{3}{|c|}{ Tingkat Hafalan } & \multirow{2}{*}{$\begin{array}{c}\text { Total } \\
\text { Sedang }\end{array}$} \\
\cline { 2 - 4 } & Rendah & Sedang & Rendah & 53 \\
\multirow{2}{*}{ IPA } & 15 & 22 & 16 & $53 \%$ \\
& $12,9 \%$ & $19,0 \%$ & $13,8 \%$ & $45,7 \%$ \\
\hline \multirow{2}{*}{ IPS } & 14 & 17 & 8 & 39 \\
& $12,1 \%$ & $14,7 \%$ & $6,9 \%$ & $33,6 \%$ \\
\hline \multirow{2}{*}{ IBB } & 1 & 9 & 0 & 10 \\
& $0,9 \%$ & $7,8 \%$ & $0,0 \%$ & $8,6 \%$ \\
\hline \multirow{2}{*}{ IIK } & 0 & 6 & 8 & 14 \\
& $0,0 \%$ & $5,2 \%$ & $6,9 \%$ & $12,1 \%$ \\
\hline \multirow{2}{*}{ Total } & 30 & 54 & 32 & 116 \\
& $25,9 \%$ & $46,6 \%$ & $27,6 \%$ & $100 \%$ \\
\hline
\end{tabular}

Berdasarkan tabel 7 dapat diketahui dari 116 responden terdiri dari 53 orang $(45,7 \%)$ berada di kelas IPA, 39 orang $(33,6 \%)$ berada di kelas IPS, 10 orang $(8,6 \%)$ berada di kelas IBB, dan 14 orang $(12,1 \%)$ berada di kelas IIK. Dari 53 peserta didik yang berada di kelas IPA, mayoritas sebanyak 22 peserta didik (19\%) memiliki hafalan pada tingkat sedang, 16 peserta didik $(13,8 \%)$ berada pada tingkat tinggi, dan 15 sisanya (12,9\%) memiliki hafalan pada tingkat rendah. Selanjutnya dari 39 peserta didik yang berada di kelas IPS, mayoritas memiliki hafalan pada tingkat sedang sebanyak 17 peserta didik $(14,7 \%), 14$ peserta didik $(12,1 \%)$ berada pada tingkat hafalan rendah, dan 8 peserta didik $(6,9 \%)$ berada pada tingkat hafalan tinggi. Kemudian dari 14 peserta didik yang berada di kelas IIK, mayoritas memiliki hafalan pada tingkat tinggi sebanyak 8 peserta didik $(6,9 \%)$, dan 6 peserta didik $(5,2 \%)$ berada pada tingkat hafalan sedang. Selanjutnya dari 10 peserta didik yang berada di kelas IBB, mayoritas memiliki hafalan pada tingkat sedang sebanyak 9 peserta didik $(9,8 \%)$, dan 1 peserta didik $(0,9 \%)$ berada pada tingkat hafalan rendah.

Merujuk pada ketiga alat ukur diatas maka dapat diambil kesimpulan bahwa rata-rata keefektivitasan hafalan peserta didik berada pada tingkat sedang, baik dari jenis kelamin, asal madrasah ataupun asal kelas.

\section{Efektivitas Outcomes}

Evaluasi Outcome diarahkan sampai seberapa jauh implikasi dari product. Outcome dalam sebuah program merupakan barang jadi (final product) yang dikehendaki setelah proses produksi atas input (Purwanto, 2014 , p. 23). Evaluasi outcome digunakan untuk mengetahui bagaimana kiprah hasil dari suatu program pendidikan selanjutnya (Suryono, 2015, p. 178). Final product program madrasah tahfidz dievaluasi melalui dua komponen, yang terdiri dari; meningkatnya hafalan peserta didik dan peserta didik mengamalkan akhlakul karimah dari Alquran.

Pertama, peserta didik sebagian sudah mampu dan mau untuk menghafalkan Alquran secara mandiri diluar jam kelas. Karena pada prinsipnya hafalan di luar jam pelajaran tahfidz diperbolehkan tanpa mengganggu kegiatan belajar mengajar. Selain diperbolehkan untuk menghafalkan di luar jam, peserta didik juga diberikan pekerjaan rumah dengan membaca ayat tertentu selama seminggu setelah maghrib. Karena dengan seringnya membaca maka peserta didik akan hafal dengan sendirinya. Peserta didik selain diberikan tugas di rumah juga diminta untuk mengaplikasikan hafalannya ketika sholat (Luthfiana, 2019).

Di sisi lain antusias dan semangat peserta didik MAN 2 Yogyakarta sudah mencapai $70 \%$, sisanya sudah proses untuk memahamkan bahwa program tahfidz ini sangat penting (Mahardika, 2019). Keantusiasan ini dapat dikondisikan dengan pembiasaan kebudayaan, percontohan, kegiatan, dan program yang diagendakan oleh madrasah. Peningkatan terlihat dari hasil perkembangan hafalan peserta didik sangat luar biasa. Hal ini dibuktikan dengan sudah adanya wisuda tahfidz dari masing-masing madrasah tanpa difasilitasi oleh Kanwil Kemenag DIY (Imanah, 2018).

Kedua, keaktifan peserta didik dalam mengikuti program tahfidz sudah banyak terlihat baik di MAN 1 Yogyakarta ataupun MAN 2 Yogyakarta. Sudah 80\% keaktifan 
peserta didik dalam menghafalkan Alquran. Walaupun masih terdapat peserta didik yang tidak bersemangat ketika mengikuti pelajaran tahfidz. Beberapa peserta didik sudah banyak yang bersemangat aktif dalam menghafal dan sisanya masih perlu untuk diingatkan (Suyanto, 2019).

Peserta didik MAN 2 Yogyakarta sudah cukup aktif dalam pembelajaran tahfidz. Peserta didik dipahamkan dan mulai tergugah untuk membaca Alquran dengan sendirinya. Melalui keaktifan ini akhirnya semua peserta didik sudah mulai sadar untuk membawa Alquran masing-masing ketika pembelajaran. Peserta didik juga sudah membudayakan antri ketika ujian. Mereka juga sangat bersemangat ketika dibuka pendaftaran wisuda tahfidz (Rahmat, 2019). Bapak Fajar menilai bahwa ini merupakan rasa untuk saling kompetitif dalam hal kebaikan atau positif dan munculnya kemandirian peserta didik, yang ditumbuhkan dari kebiasaan menghafal dan dekat dengan Alquran.

\section{KESIMPULAN DAN REKOMENDASI}

Berdasarkan penelitian di atas dapat disimpulkan bahwa efektivitas keseluruhan program madrasah tahfidz Kementerian Agama DIY yang diterapkaan pada MAN 1 Yogyakarta dan MAN 2 Yogyakarta dikatakan "cukup efektif". Hal ini terlihat dari tiga komponen yaitu input, proses, dan outcome dari lima komponen evaluasi CIPPO terpenuhi secara optimal. Sedangkan dua komponen lainnya yaitu pertama, konteks tidak efektif karena tujuan program dinilai kurang tepat sasaran. Dimana peserta didik seharusnya lebih membutuhkan tahsinul quran dibanding hafalan juz 2. Kedua, produk tidak efektif karena rata-rata keefektivitasan hafalan peserta didik pada tingkat sedang dengan prosentase $(46,6 \%)$.

Hasil penelitian ini dapat menjadi refleksi dan memberikan rekomendasi kepada pemangku kebijakan yaitu seksi pendidikan madrasah Kementerian Agama Daerah Istimewa Yogyakarta untuk "merevisi program". Hal ini dikarenakan masih terdapat 2 komponen yang dinilai tidak efektif. Masih perlu diadakannya penelitian lanjutan untuk meningkatkan efektivitas program madrasah tahfidz.

\section{REFERENSI}

Andi. (2017). Branding Madrasah melalui Potensi untuk Tingkatkan Daya Saing. Retrieved from 23 Februari website: http://edupost.id/beritapendidikan/branding-madrasah-melaluipotensi-untuk-tingkatkan-daya-saing/

Arifin, Z. (2009). Evaluasi Pembelajaran Prinsip, Teknik, Prosedur. Bandung: PT. Remaja Rosdakarya.

Asrori, M. A. dan M. (2014). Metodologi dan Aplikasi Riset Pendidikan. Jakarta: Bumi Aksara.

Fauzi, A. (2019). Wawancara Kepala Seksi Sarana dan Prasarana Bidang Pendidikan Madrasah Kementerian Agama Daerah Istimewa Yogyakarta Tahun 2015.

Imanah, N. (2018). Hasil Wawancara Kepala Seksi Kurikulum dan Evaluasi Bidang Pendidikan Madrasah Kementerian Agama Daerah Istimewa Yogyakarta.

Jaeun, S. L. dan A. (2014). Evaluasi Pelaksanaan Program S1 PGSD di Unit Program Belajar Jarak Jauh UT DIY. Jurnal Kependidikan, 44(1).

Laili, N. A. (2019). Wawancara Guru tahfidz MAN 1 Yogyakarta.

Len. (2018a). 95 Siswa MAN 2 Yogya Ikuti Wisuda Tahfidz. Retrieved from April 10 website:

https://yogyakarta.kemenag.go.id/index.p $\mathrm{hp} / \mathrm{web} /$ berita/95-siswa-man-2-yogya-

ikuti-wisuda-tahfidz

Len. (2018b). Peringati Harlah ke 40 MAN 2 Yogya Gelar Serentetan Kegiatan. Retrieved from 26 Maret website: http://man2yogyakarta.sch.id/2018/03/26 /peringati-harlah-ke-40-man-2-yogyagelar-serentetan-kegiatan/

Luthfiana, P. (2019). wawancara Guru tahfidz MAN 1 Yogyakarta.

Mahardika, P. (2019). Wawancara Guru tahfidz MAN 2 Yogyakarta.

Mardhiyah, U. A. (2017). Efektivitas Pembelajaran Baca Tahsin Hafalan Alquran (BTHQ) dalam meningkatkan 
Hafalan Alquran Peserta Didik di SDIT Luqman Al-Hakim Yogyakarta. Pascasarjana UIN Sunan Kalijaga.

Mt/dzl. (2017). Tabligh Akbar dan Wisuda

Tahfidz Rayakan Peringatan Hari Santri di MAN 1 Yogyakarta. Retrieved from 24 October website: http://manyogya1.sch.id/berita/2018/324/ 0/Tabligh-Akbar-dan-Wisuda-TahfidzRayakan-Peringatan-Hari-Santri-diMAN-1-Yogyakarta.html

Mukotip. (2018). Wawancara Kepala Seksi Kelembagaan dan Sistem Informasi Madrasah Bidang Pendidikan Madrasah Kementerian Agama Daerah Istimewa Yogyakarta.

Nurhadi, A. L. A. dan D. (2018). Modul Pembelajaran Tahfizh Madrasah Aliyah (MA) Kelas XI. Yogyakarta: Bidang Pendidikan Madrasah Kantor Wilayah Kementerian Agama Daerah Istimewa Yogyakarta.

Purwanto. (2014). Evaluasi Hasil Belajar. Yogyakarta: Pustaka Pelajar.

Rahmat, F. B. (2019). Wawancara Wakil Kepala Madrasah bidang Keagamaan MAN 2 Yogyakarta.

Safruddin, S. A. dan C. (2014). Evaluasi Program Pendidikan, Edisi Kedua. Jakarta: Bumi Aksara.

Sugiyono. (2013). Metodologi Penelitian Pendidikan: Pendekatan Kuantitatif, Kualitatif, dan $R \& D$. Bandung: Alfabeta. Sugiyono. (2015). Metode Penelitian
Manajemen. Bandung: CV. Alfabeta.

Sukmadinata, N. S. (2012). Metode Penelitian Pendidikan. Bandung: Remaja Rosda Karya.

Suryono, N. H. dan Y. (2015). Evaluasi Keberhasilan Program Taman Bacaan Masyarakat dalam Meningkatkan Minat Baca Masyarakat di Derah Istimewa Yogyakarta. Jurnal Pendidikan Dan Pemberdayaan Masyarakat, 2(2).

Suyanto. (2019). Hasil Wawancara Wakil Kepala Madrasah Bidang Keagamaan MAN 1 Yogyakarta.

Undang-Undang No 20 Tahun 2003 tentang Sistem Pendidikan Nasional. , (2003).

Uswatun, H. (2019). Wawancara Kepala Seksi Pendidikan Madrasah Kementerian Agama Kota Yogyakarta.

Wahyudhiana, D. dan. (2015). Model Evaluasi Program Pendidikan. Islamadina, XIV(1).

Widoyoko, E. P. (2014). Evaluasi Program Pembelajaran; Panduan Praktis bagi Pendidik dan Calon Pendidik. Yogyakarta: Pustaka Pelajar.

Zahro', I. B. (2017). Strategi Guru dalam Meningkatkan Efektivitas Hafalan Alquran (Studi Multi Situs di SDI AlAzhar Kedungwaru Tulungagung dan SD Al-Gontory Tulungagung). Pascasarjana Institut Agama Islam Negeri Tulungagung. 